\title{
International Investment and Colonial Control: A New Interpretation
}

\section{Citation}

Frieden, Jeffry A. 1994. International investment and colonial control: A new interpretation. International Organization 48(4): 559-593.

\section{Published Version}

http://journals.cambridge.org/action/displayJournal?jid=INO

\section{Permanent link}

http://nrs.harvard.edu/urn-3:HUL.InstRepos:2623303

\section{Terms of Use}

This article was downloaded from Harvard University's DASH repository, and is made available under the terms and conditions applicable to Other Posted Material, as set forth at http:// nrs.harvard.edu/urn-3:HUL.InstRepos:dash.current.terms-of-use\#LAA

\section{Share Your Story}

The Harvard community has made this article openly available.

Please share how this access benefits you. Submit a story.

\section{Accessibility}




\title{
International investment and colonial control: a new interpretation
}

\author{
Jeffry A. Frieden
}

The relationship between international investment and military conflict has long been a theme of scholarly and popular debate. The most famous focus of discussion was the Hobson-Lenin thesis that modern colonial imperialism could be traced to overseas investments by finance capitalists, but there are many variants of the dispute. While these topics appear largely of historical interest, they also raise broad issues in international political economy. Inasmuch as colonialism is a particularly virulent form of interstate conflict (both among potential colonial powers and between colonizer and colonized), explaining it may help shed light on international conflict and cooperation more generally.

This article recasts the relationship between international investment and colonialism in a more general context. Putative ties between metropolitan investment and colonial control are one subset of a problem associated with the monitoring and enforcement of property rights across national jurisdictions. Cross-border investment involves an implicit or explicit contract between the host country and the investor. The arrangements developed to monitor and enforce these contracts-from gunboat diplomacy to private negotiations-are varied institutional forms responding to different characteristics of the investments and the environment. Colonialism is a particular, perhaps particularly noxious, form that the "resolution" of these quasi-contractual issues can take: the use of force by a home government to annex the host region and so eliminate the interjurisdictional nature of the dispute.

I would like to acknowledge the Social Science Research Council's Program in Foreign Policy Studies, the German Marshall Fund, and UCLA's Center for International Relations for supporting the research reported herein. I also thank Fred Halliday, Jack Hirshleifer, Stephen. Krasner, David Lake, Peter Lindert, Lisa Martin, John Odell, Robert Powell, Ronald Rogowski, Richard Rosecrance, John Ruggie, Kenneth Thomas, Michael Waldman, and Mira Wilkins for helpful comments and suggestions; and Carlos Juarez and Roland Stephen for research assistance. 
This approach leads to two principal dimensions of variation in overseas investments expected to be associated with different levels of interstate conflict and the propensity for such investments to have been involved in colonialism. The first is the ease with which rents accruing to investments can be appropriated by the host country, or protected by the home country, by coercive means. Everything else being equal, the more easily rents are seized, the more likely the use of force by home countries. The second dimension is the difference between the net expected benefits of cooperation among home countries as compared with unilateral action by a single home country. This is a function both of the degree to which interinvestor cooperation facilitates monitoring and enforcing property rights to the investment and of the cost of organizing and sustaining such concerted action by home countries. All else being equal, the lower the net expected benefits of cooperation, the more likely are home countries to engage in unilateral action, including colonialism.

Certain types of investments appear to have lent themselves more easily than others to protection by the unilateral use of force by home governments. This is especially true for investments with site-specific and easily appropriated rents, such as raw materials extraction and agriculture. For such investments, colonial control resolved inherent property rights problems that arose in its absence. This is not to say that these investments caused colonialism, for the reverse might have been the case-the greater security colonialism offered might have attracted disproportionate amounts of certain kinds of investments; it is, however, to argue for an affinity between certain cross-border investments and colonialism. I do not claim that these factors exhaust all explanation. Clearly geopolitical, technological, ideological, and other forces were important; but the sorts of differentiated economic variables discussed here often have been neglected in studies of colonialism. Further, their importance appears confirmed by historical evidence.

The first section reviews the long-standing dispute over colonialism and foreign investment, reshaping it in more general terms. The next section goes on to redefine the analytical issues in the context of property rights and contractual problems inherent in cross-border investment and to explore the implications for the study of colonialism. The third section presents more specific hypotheses about the effects different sorts of overseas investments are expected to have on the attractiveness of colonial control (and vice versa) and about the likely distribution of types of investment among colonial and noncolonial countries. The fourth section examines rudimentary data about the relationship between different types of investment and different forms of rule, while the fifth section brings more qualitative historical evidence to bear on this problem. The final section summarizes the conclusions of this analysis and discusses its implications. 


\section{Colonialism and international investment: the issues}

Debates over the role of foreign investment in conflict between investing and receiving societies and in conflict among investing countries have a long history. ${ }^{1}$ Early in this century, Marxists and others carried on spirited polemics over the prospects for cooperation and conflict among advanced capitalist states in the context of dramatic increases in international investment and growing international strife (including World War I) that seemed to many to be tied to economically based colonial rivalries. ${ }^{2}$ The 1930 s and 1940 s gave rise to new debates over foreign investment and international conflict. ${ }^{3}$ Indeed, some of the impetus for the Bretton Woods institutions built during the early postwar years came from a desire to avoid problems associated with international investment that were perceived to have contributed to the political turmoil of the first half of the twentieth century. ${ }^{4}$

Elaborate plans to manage disputes among investing countries became superfluous, as such conflicts practically disappeared over the postwar period. ${ }^{5}$ Nonetheless, the topic remains interesting and important, for it involves enduring issues in international conflict and speaks to the relationship between international economics and politics.

Unfortunately, the analysis of these issues is rife with confusing and often misleading arguments. Proposed explanations (independent variables) typically are poorly specified; in fact, in the most prominent focus of the debate, they are close to meaningless. The things to be explained (dependent variables) similarly are poorly stated. Below, I try to reorganize both the independent and dependent variables to permit clearer analysis.

1. The most important recent contribution to the debate is Charles Lipson, Standing Guard: Protecting Foreign Capitat in the Nimeteenth and Twentieth Centuries (Berkeley: University of California Press, 1985). Lipson raises issues similar to those discussed here. Though his explanatory argument differs, it is not contradictory to that presented in this article.

2. Lenin and John Hobson were the two best-known analysts of these problems. Apart from Lenin's pamphlet Imperialism: The Highest Stage of Capitalism (New York: International Publishers, 1939), a summary of his position is contained in V. I. Lenin, introduction to Imperialism and World Economy by Nikolai Bukharin (New York: International Publishers, 1929), Pp. 9-14. An outstanding survey of Hobson's theoretical position can be found in Peter Cain, "I. A. Hobson, Financial Capitalism, and Imperialism in Late Victorian and Edwardian England," Joumal of Imperial and Commonwealth History 13 (May 1985), pp. 1-27.

3. The two most influential studies were those by Herbert Feis and by Eugene Staley, who looked at previous experiences, especially with European overseas investments, as a guide to potential future arrangements. See Herbert Feis, Europe, the World's Banker 1870-1914 (New Haven, Conn: Yale University Press, 1930); and Eugene Staley, War and the Private Investor (Garden City, N.Y.: Doubleday, Moran, and Co., 1935).

4. On the Bretton Woods negotiations, see Richard N. Gardner, Sterling-Dollar Diplomacy in Current Perspective (New York: Columbia University Press, 1980); and Armand Van Dormael, Bretton Woods (New York: Holmes and Meier, 1978).

5. Contrarily, such plans simply may have been extraordinarily successful so as to render the issue of conflict obsolete. This possibility does not accord with the widespread impression that Bretton Woods institutions did very little of what they were intended to do, and very little at all until the 1960s. 
Most controversy over colonialism and foreign investment has to do with the so-called economic theory of imperialism. ${ }^{6}$ The debate seems peculiar to the student of political economy, for it revolves around the simple question of whether economic considerations were important to colonial imperialism or not. As such it is not about an economic theory as normally understood but rather about the relative importance of the totality of economic concerns and the "contending" totality of noneconomic concerns, even though all scholars agree that both were present. This confusion is compounded by all sides in the debate. Supporters of the "economic approach" point to instances in which nationals of a colonial power made money as a result of colonialism, while opponents call upon examples of colonial possessions devoid of economic significance. If the question were whether colonialism was solely and entirely motivated by expectations of direct and measurable economic profits, this might be appropriate; inasmuch as this is manifestly not the question scholars ask, it is not.

In general, an economic theory of political behavior tries to correlate different kinds of economic activity with different kinds of policy or political outcomes. For example, some common economic theories of politics hypothesize a relationship between firm and industry characteristics on the one hand and levels of support for trade protection, regulatory outcomes, or other government actions on the other. Typically, an economic explanation is not about the relationship between the economy and politics in general but rather about the relationship of a specific economic independent variable to a specific political or policy dependent variable. It is variation in the economic variable that is purported to explain corresponding variation in the political or policy outcome. If so desired, confrontation with noneconomic theories can then be made by seeing whether noneconomic variables outperform economic variables in explaining outcomes; more commonly, scholars accept that economic and noneconomic factors are not mutually exclusive. In any case, the appropriate test of a typical economic theory is not whether or not economic considerations matter, but whether they matter in the ways hypothesized by the theory in question. An economic theory of colonialism, in this context, would correlate particular kinds of economic activities with the likelihood of colonial rule.

It is also useful to get a clearer sense than is usually provided in the debate over colonialism of what is being explained by contending theories. Colonial rule is but one possible outcome of relations between and among countries-

6. Influential statements or surveys of the positions at stake include Benjamin J. Cohen, The Question of Imperialism: The Political Economy of Dominance and Dependence (New York: Basic Books, 1973); D. K. Fieldhouse, "Imperialism: An Historiographical Revision," Economic History Review 14 (December 1961); David Landes, "Some Thoughts on the Nature of Economic Imperialisn," Joumal of Ecomomic History 21 (December 1961); and Joseph Schumpeter, "The Sociology of Imperialisms," in Joseph Schumpeter, Imperialism and Social Classes (New York: Augustus Kelley, 1951), pp. 3-130. 
one value that the dependent variable can take. Its uniqueness is twofold. First, it involves the explicit or implicit use of force by the colonial power over the annexed region. Second, the relationship is exclusive; that is, the colonial power acts unilaterally and not in concert with other powers (and often explicitly to exclude them).

To express the thing to be explained more generally, colonialism is simply one example of interstate interaction occurring along two dimensions. [For ease of exposition, I refer to potential colonial powers as "home countries" (that is, sources of foreign investment) and to potential colonized regions as "host countries" (that is, sites of foreign investment). \} The first dimension of variation is the extent to which a home country engages in the use or threat of military force in its relations with the host country. Variation along this dimension runs from military intervention at one limit to the absence of government involvement at the other. The second dimension is the degree to which home countries act in concert toward a host country. Variation along this dimension runs from unilateral and exclusionary action by a home country at one limit to cooperative multilateral action by many home countries at the other. Those so inclined might imagine a two-by-two matrix with the use of force (or conflict more generally) between home and host countries on one axis and conflict among home countries on the other. The four positions described here would occupy the four cells (home-host and home-home conflict is colonialism, home-host and home-home cooperation is peaceful multilateral negotiation, and so on), but there is no reason to believe that variation does not allow for a continuum of outcomes. In this context, colonialism (the unilateral use of force) is one possible outcome. Other potential outcomes include multilateral use of force, bilateral arms-length negotiations, or multilateral negotiations - and gradations in between.

Other characteristics of home-country policy may well be of interest. For example, it may be important to understand the domestic distributional implications of a government's policy toward the foreign assets of its citizens, such as the subsidization of overseas investors by national taxpayers. It may also be important to understand the ways in which relations between home and host countries, or among home countries, are institutionalized at the international level. ${ }^{7}$ Other potential topics suggest themselves, but I focus on those mentioned above.

In any case, the issues addressed here involve home-country conflict with host countries and conflict among home countries. These capture much of the theoretical debate and historical experience. Putting the two dimensions together covers everything from unilateral military intervention leading to colonial annexation, through multilateral intervention that preserves the

7. For a discussion of the analytical issues in the development of such international institutions, see Robert Keohane, "International Institutions: Two Approaches," Intemational Studies Quarterly 32 (December 1988), pp. 379-96. See also Michele Fratianni and John Pattison, "The Economics of International Organization," Kyklos 35 (1982), pp. 244-62. 
sovereignty of the host nation, to private bilateral or multilateral negotiations. This redefines the outcome of interest, so that colonialism is one of several possible results of home-home and home-host interaction; in other words, it describes variation in the dependent variable. The next step is to focus on the explanatory variable proposed, which is differing characteristics of international investment.

The following section explores the impact of various kinds of international investments on the policies of potential colonial powers, up to and including colonialism. It ignores many other issues, such as investments among developed countries, except where these impinge directly on the theme. The article also ignores potentially important noneconomic factors that might have affected colonial rule. I have done so only to delimit the problem in a manageable way; I certainly do not wish to deny the importance of other considerations, only to plead for the incorporation of certain economic concerns into explanations of a complex reality. Excluded from the analysis by design is consideration of military, geopolitical, technological, and a host of other factors. I have dealt with some of these in a limited way elsewhere; for now I focus on the economic nature of international investment. ${ }^{8}$

\section{International investment, property rights, and international conflict}

The international politics of international investment are largely organized around two broad problems. The first is the desire of investors to monitor and enforce the host country's respect for cross-border property rights. The second is the degree to which different foreign investors engage in collective action to carry out these monitoring and enforcement activities.

The security of property across borders is in essence a contractual problem. Overseas investment involves an implicit or explicit contract between the investor and the host state. ${ }^{9}$ This contract may commit a host government to

8. See Jeffry A. Frieden, "The Economics of Intervention: American Overseas Investments and Relations with Underdeveloped Areas, 1890-1950, "Comparative Studies in Society and History 31 (January 1989), pp. 55-80, which also presents some of the ideas contained in the present article. The facts that I exclude other potential explanatory variables from my analysis and that I do not weigh the large number of contending explanations are a problem only if there is reason to believe that one of the alternate explanatory variables is correlated with mine and may outperform it. One exception is the role of economic development, which is probably correlated with types of investment; indeed, in the essay cited above I suggest a complex interaction among development, foreign investment, and foreign intervention. In this context and more generally, it is nonetheless legitimate to argue for the validity of my hypotheses as part of a full explanation of the phenomena in question.

9. An explicit discussion of this concept, specifically in regard to sovereign lending, can be found in Vincent P. Crawford, Intemational Lending, Long-term Credit Relationships, and Dynamic Contract Theory Princeton Studies in International Finance, no. 59 (Princeton, N.J.: International Finance Section, 1987). Further references to this very large literature can be found therein. 
repay a loan, to allow a firm to mine copper, or to permit the establishment of a local branch factory of a multinational corporation. If the host government breaks the contract-by not servicing the loan, expropriating the mine, or closing down the factory-foreign investors have no direct recourse. This requires investors to devise some mechanism to monitor and enforce their property rights. In this sense home-country military force is one choice among a number of devices to protect overseas assets.

All investors face contractual or quasi-contractual problems in the course of business; this fact is central to modern analyses of industrial organization. ${ }^{10}$ The existence of a state domestically does not solve the problem, for it is costly to recur to the court system. Investors come up with a variety of ways to overcome contractual problems, ranging from the use of forward markets through long-term agreements in which both parties make irreversible investments (what Oliver Williamson terms "mutual hostages"), to vertical integration. ${ }^{11}$

Regarding the security of property across borders as a problem in relational contracting directs attention to characteristics of the assets, product markets, and informational environment that affect the ability of the parties to monitor and enforce their contract. Variation in such contractual problems in turn gives rise to different organizational or political responses. ${ }^{12}$

In addition to underlying contractual questions, the need for investors to monitor and enforce host-country compliance can lead to problems of collective action. In many cases, of course, property rights can be secured on a purely individual basis so that there is no incentive for investor collaboration. All investors may have a common interest in ensuring stable rights to private property, but this does not mean that such stable rights must necessarily be provided to all investors. ${ }^{19}$ Each investor is first concerned about the investor's own property rights, and an investor can, in fact, benefit by receiving exclusive property rights. Where secure property rights can be supplied on a specific basis to specific investors, there is little reason for cooperation among investors.

On the other hand, the protection of foreign property may be made substantially more effective if investors cooperate. Whenever the combined action of many investors reduces the cost of protecting their property to each

10. An influential example of such an analysis with an explicit contractual emphasis is Oliver Williamson, The Economic Institutions of Capitalism (New York: The Free Press, 1985).

11. Ibid., pp. 169-205.

12. The approach presented here is related to that of Keohane; see Robert O. Keohane, "The Demand for International Regimes, ${ }^{13}$ Intemational Organization 36 (Spring 1982), pp. 325-55. Keohane also relies on the relational contracting literature, especially as regards the role of institutions in reducing transactions costs, in his explanation of regime persistence.

13. In what follows I focus on property rights. The discussion could be extended to include many other policies, from taxation and tariffs to labor relations. In virtually all instances, the same tension between general and specific investor interests recurs. I emphasize property rights partly because they are in some sense primordial-without security of property few other policies matter - and partly because the general point can easily be broadened to other issues. 
investor, cooperation would be desirable to them. This might be the case, for example, when evaluating the host government's compliance with contractual commitments can be costly-such as when it is difficult to separate the impact of exogenous events from straightforward cheating. In this case, crucially important accurate information about the host government's actions and intentions serve all interested investors, and it is in the interest of all to cooperate in obtaining the information. Another example might be when the threat of sanctions by investors (or their governments) leads to host-country recognition of cross-border property rights to all (or a broad class of) foreign investors. The more investors (or countries) participate in the sanctions, the more effective they will be for all. ${ }^{14}$

However, the circumstances that can make cooperation attractive to investors can also make it difficult. If the benefits of joint action accrue to larger groups of (or all) foreign investors, such protection may come to take on the characteristics of a public good. Under these circumstances, a host government's commitment to respect the property of foreign investors (or a class of foreign investors) is indivisible, inherently available to all investors (or all members of a class of investors). When monitoring and enforcing compliance with quasi-contractual commitments to property rights serves a large class of (or even all) investors, there may be collective action problems associated with the provision of this public good. ${ }^{15}$ Because the public good would benefit a large group of actors, actors have an incentive to cooperate to help provide it; cooperation is hindered by the fact that noncooperators cannot be excluded from benefiting from the provision of the public good. ${ }^{16}$

The more the protection of property requires joint action to accomplish, the greater the potential gains from cooperation; but the more difficult collective action, the less likely such cooperation is to succeed. Where joint action by international investors to monitor and enforce property rights improves their welfare, the probability of successful cooperation is a function of free-rider problems. To summarize: cooperation among investors becomes more likely as the potential return to investor collaboration increases (i.e., the more monitoring and enforcement are public goods). And as collaboration among investors becomes more likely, the easier it is to organize collective contribution to monitoring and enforcement. ${ }^{17}$ Emphasizing these considerations is not to

14. For an analysis of sanctions, see Lisa L. Martin, Coercive Cooperation: Explaining Multilateral Economic Sanctions (Princeton, N.J.: Princeton University Press, 1992).

15. For a discussion of monitoring and enforcement assurances serving as a welfare-improving public good, see Douglass North and Barry Weingast, "Constitutions and Commitment: The Evolution of Institutions Governing Public Choice in Seventeenth-Century England," Joumal of Economic Fistory 49 (December 1989), pp. 803-32.

16. This broad class of problems has, of course, been the subject of an enormous literature on strategic interaction, to which I allude only in passing here.

17. Jack Hirshleifer, "From Weakest-link to Best-shot: The Voluntary Provision of Public Goods," Public Choice vol. 41, no. 3, 1983, pp. 371-86. Hirshleifer differentiates among different types of collective action problems that concern the provision of public goods in ways that are applicable to the present setting. In a "weakest link" context, supply is a function of the smallest 
downplay the importance of other, noneconomic, elements; it is to argue for the anticipated political implications of these economic factors, all else being equal.

Thus the two dimensions of variation in the characteristics of international investment that I expect will affect the probability that such investment will be associated with colonial rule may be summarized as follows: the first is the ability of the investment to be protected by force; the second is the degree to which monitoring and enforcing a host government's respect for foreign property has the character of a public good, and (if it does) the difficulties in overcoming collective action problems to supply the public good.

\section{International investment and conflict: analytical expectations}

The preceding discussion is only useful inasmuch as it leads to otherwise nonobvious analytical expectations. In what follows, I summarize features of cross-border investments and of the markets in which those investments operate, both of which I expect will affect the character of the monitoring and enforcement of international property rights and the degree of collaboration among international investors in pursuit of this monitoring and enforcement. In other words, variation in these factors should be associated with (1) variation in home-state use of force against a host state and (2) the degree of home-state cooperation over investments of this type. Once again, these should be taken as. potentially contributory rather than necessarily competing variables in a complex explanation that includes a wide variety of economic, political, military, cultural, and other considerations. For my more limited purposes, the factors relevant to this evaluation of the use of force by and cooperation among investing countries can be grouped into the two categories described above and then can be applied to particular classes of investments.

\section{Site specificity and the costs of physical protection}

Some assets can be more easily protected, and some contracts more easily enforced, by the use or threat of force than others. Put another way, the rents accruing to some assets can be more easily appropriated or protected by force than the rents accruing to other assets. To some extent, the appropriability of the asset and its income stream is related to the asset's specificity to a particular site or corporate network. For example, the income stream created by a copper mine is specific to the place where the copper is located. The mine, and the resource rents associated with it, can be seized by a host country with relative

contribution, while in a "best shot" setting, it depends on the largest contribution. In the formet case, Hirshleifer shows, the level of the public good provided will be much larger thath in the latter. 
ease. On the other hand, the income stream accruing to a branch plant of a manufacturing multinational corporation typically is specific to its participation in a global enterprise-it relies on managerial, marketing, or technological inputs available only within the firm. While the host government can seize the factory, it cannot appropriate the rents.

By the same token, site-specific assets can be protected by force on the part of investors or their home countries. A mine or plantation can be retaken from a host government by force, and it can continue to earn income once retaken, especially if it is producing for export. While a branch factory can be retaken by force, inasmuch as it is integrated into the local economy-perhaps with networks of suppliers and customers - it would be unlikely to continue to earn income in such circumstances.

This leads me to expect that investing country governments will tend to use or threaten force more the easier it is for the income accruing to the asset in question to be physically seized or protected. The more the rents earned by an asset are site-specific, the more the use of force will serve to protect them, and hence the more likely it is to be used.

\section{Net expected benefits of investor cooperation}

Leaving aside whether or not investors and their home countries use force, we want to understand the circumstances under which investors cooperate with one another instead of pursuing unilateral solutions (including colonialism). I assume the goal of cooperation would be to monitor and enforce the host country's compliance with explicit or implicit contractual commitments. ${ }^{18} \mathrm{I}$ expect cooperation among investors to be more common when the net expected benefits of collaborative action compare favorably with those of private enforcement by a single investor.

As discussed above, one important determinant of the benefits of collective action is the degree to which monitoring and enforcement become easier for each investor as more investors participate. At one extreme, the cost of monitoring an agreement can be the same for each investor no matter how many there are. This might be the case when each firm must observe aspects of the contract specific to itself; no matter how many firms are in similar situations, no one firm's efforts affect those of any other firm. At the other extreme, there may be significant economies of scale in monitoring and enforcing an agreement, such that the cost per firm declines steeply with the number of investors.

18. Contractual monitoring and enforcement costs are essentially the same as transactions costs. For a survey of transaction costs, see Oliver Williamson, "Transaction Cost Economics," in $R$. Schmalensee and R. D. Willig, eds., Handbook of Industrial Organization, vol. 1 (Amsterdam: Elsevier, 1989). I use the longer term because it is more specific as to the costs involved and can more readily be broken down into component parts for the purposes of more detailed discussion. 
This continuum applies to monitoring and enforcement costs. If a debtor threatens default on foreign [oans, information about the government's solvency, macroeconomic conditions, and other contingencies may be valuable to all creditors. This information is essentially the same for all creditors, and if they each contribute a small amount toward a common effort to obtain the information, they will be better off than if each goes about trying to gather the data on its own. By the same token, in some instances each investor has effective ways of punishing a host government that violates a contract. The owner of a mine that is nationalized might withhold technological information without which the mine cannot run and which is not available elsewhere. In other instances, however, cooperation among investors may be necessary to ensure effective enforcement. Perhaps the technology in question is available to a dozen foreign mining firms; all would need to participate in withholding this technology for the sanctions to bind.

Monitoring and enforcement both may be characterized by diminishing costs (increasing returns) for many reasons. ${ }^{19}$ For my purposes, it is enough to observe that the incentives for investors to cooperate in monitoring and enforcing contractual compliance by host governments increase the more such efforts are characterized by diminishing costs (increasing returns); the specifics of each case can be examined separately.

Nevertheless, it is also necessary to look at the costs of organizing such beneficial cooperation. As the number of investors rises, if the increased benefits of monitoring are outweighed by the increased costs of holding an ever more fractious group of investors together, then cooperation will not be stable.

The costs of obtaining and sustaining cooperation are a function of well-known collective action considerations. As mentioned above, the cooperative monitoring and enforcement of cross-border contractual commitments by a host country can have characteristics of a public (or at least a club) good. Using the earlier example of creditors who agree to cooperate to monitor a troubled debtor, if all the creditors expect the information to be gathered by others and shared with them, no single creditor has an incentive to contribute toward its gathering. Similarly, creditors who agree to impose sanctions on a recalcitrant debtor face the problem that while all benefit from successful sanctions, no one creditor alone has an incentive to impose the sanction.

Many circumstances conduce toward reducing free riding. These include relatively small numbers, so that all members of the group can observe which members are not contributing and try to design effective sanctions; selective incentives, by which those who contribute can be rewarded; and long time horizons, which increase incentives to cooperate by increasing the expected benefits of cooperation. All of these conditions vary from international

19. Diminishing costs of (increasing returns from) monitoring are a common feature of much of modern industrial organization. They are, for example, central to many interpretations of the role of financial intermediaries. See Douglas Diamond, "Financial Intermediation and Delegated Monitoring," Review of Economic Studies 51 (July 1984), pp. 393-414. 
investment to international investment; collective action will be easier among some investors than among others. The greater the ability to control free riding, the more I expect cooperation among investors.

Some may object that these are little more than tautologous trivialities. Force is more likely where it is effective; cooperation is more likely where it yields greater net benefits to the cooperators. However, stating the problem and the potential explanatory variables as above allows for analytical predictions that are not obvious. Some examples of how the framework can be applied to different sorts of overseas investments follow. These are broad generalizations and not meant to be exhaustive of all types of investments; but they do cover a range and illustrate the application of the approach.

Primary production for export. Overseas investments in primary production for export include both extractive industries and agriculture: for example, the mining of precious metals, copper, and oil, and the raising of sugar, cotton, and tea. Such assets are quite specific as to site and can be protected (or attacked) by force relatively easily. I expect force to be linked to them more than to other investments.

Monitoring and enforcing property rights to extractive and agricultural investments are not, in most instances, characterized by increasing returns. One mine or plantation owner seldom benefits from eftorts by other owners to protect their own investments. There may be gains from cooperation when investors can boycott the output of a seized facility. If copper mining corporations control the world copper market, they can collude to make it impossible for a host government that nationalizes a mine to sell its product. Among other things, this will depend on how differentiated the product is (the more differentiated, the easier the embargo), how large spot markets are (the larger, the easier for the host government to evade the embargo), and other conditions. However, collective action among overseas investors in primary production cannot be assumed. It will depend on how many producers there are; on whether they are linked on some other dimension (such as marketing the product); and on other such collective action considerations.

The prediction, then, is that overseas investments in primary production for export will be more likely to be associated with the use of force. Except where an embargo of the product is technically feasible and free riding can be readily combatted, these investments also will be more likely to be associated with unilateral action by home countries. In addition to the use of force, such investment will be correlated with other unilateral action, such as intervention or colonial annexation.

Affliates of manufacturing multinational corporations. Modern theories emphasize that foreign direct investment, especially in manufacturing, is but a special case of the internalization of economic activities within one 
corporate entity. ${ }^{20}$ In this sense, a local affiliate is an integral part of a corporate network, and if separated from this network it loses most of its value. The assets of the local affiliate are specific to their use within a broader international enterprise, generally for technological, managerial, or marketing reasons. Most of the value of an overseas Ford affiliate, for example, is inseparable from the affiliate's connection with Ford. This may be because the affiliate makes parts (or requires inputs) which are used (or supplied) only by the parent company, or because the affiliate depends on the reputation and managerial expertise of the international firm. The host government could not appropriate most of the rents that accrue to these assets; once the assets are separated from the integrated corporation, they lose much of their value..$^{21}$

Host governments have little incentive to take assets whose value disappears with the takeover. For this reason, affiliates of integrated multinational corporations have relatively secure property rights. The more specific the assets to a corporate network, the less likely is the host government to threaten the asset, and the less likely is the firm to require home country involvement. ${ }^{22}$

The limited incentive to take such affiliates is paralleled by the difficulties a home country would have in defending a manufacturing affiliate. Unlike the typical mine, the typical branch plant is integrated into the local economy; it cannot function in protected isolation, ringed by a protective force. Similarly, because the assets of affiliates are quite specific to the global firms, there are few externalities created by the defense of one such affiliate-thus the incentive to cooperate is limited. For all these reasons, I expect very little home country political involvement in foreign direct investment in manufacturing and hence little cooperation among home countries.

Public utilities. International investment in public utilities was especially important during the century before World War II. Foreign-owned railroads, water and power plants, and urban transportation were common throughout the developing world. Such facilities are in a sense intermediate between primary production for export and manufacturing affiliates. On the one hand, like manufacturing affiliates, utilities are often fully integrated into the local economy, so that physical protection by a home government would not assure the investment's earning power: for a railroad to pay off, it has to be used by

20. For a good survey of this process of internationalization, see Richard E. Caves, Multinational Enterprise and Economic Growth (Cambridge: Cambridge University Press, 1982). On vertical integration specifically, see Martin K. Perry, "Vertical Integration: Determinants and Effects, ${ }_{1}$ in Schmakensee and Willig, Handbook of Industrial Organization.

21. Of course, in our example, the government could presumably sell the expropriated branch plant back to Ford, but few parent companies would be likely to risk double jeopardy.

22. This is too simple, of course. A host government might take over a multinational corporation affiliate in order to eliminate competition to a local firm or for other reasons. In addition, many host policies involve some sort of violation of contractual agreements. However, the general point still holds: government attempts to appropriate rents are affected by how specific those rents are to the corporate structure within which they are embedded. 
local customers. In addition, some utilities are technically sophisticated enough that local operators in developing economies might have difficulty running them. However, in many instances, utilities are site-specific and can be seized by force: this might be true of a railroad line or power plant. Force might be useful in some cases-where, for example, the railroad tine serves only to transport bananas from foreign-owned plantations to the coast-but in many others it is less likely to be practical.

Scale economies are rare in monitoring and enforcing contracts involving utilities. Each facility is likely to face specific conditions, such as rates for a power company, that in themselves have little impact on other investors in the sector. Even when different utilities face similar problems, such as foreign railroads, the returns from cooperation appear relatively low. For example, railroad companies have little with which to threaten a boycott and similarly little on which to collaborate. Information sharing might be useful, but it is likely to be limited by the different conditions faced by different firms.

For all these reasons, I expect that utilities may be seized by host countries but are unlikely to cause a use of force by home countries. I also expect little cooperation among the home countries of utilities investors. The expected pattern, then, is one of voluntary contracts and negotiations between host countries and individual owners of utilities.

Loans to governments. The practice of lending to foreign sovereigns is probably as old as the nation-state, and problems in monitoring and enforcing sovereign compliance with such loan contracts are just as old. They remain important today, although their economic form has changed over the years. The loan contract comprises a government's promise to pay and is easy for the host government to violate. Since the asset is an intangible contract, it is difficult to protect by force. An exception might arise when the lender or its home government are able to seize the income stream accruing to a debtor's asset (such as a government-owned airplane or, in earlier days, a customs house); but these are strictly limited: governments with large external assets are unlikely to need to borrow heavily.

On the other hand, the returns from cooperation are enormous. Financial markets, especially international financial markets, rely on debtor fears that default will impede future borrowing. For this threat of future borrowing difficulty to be credible, financial markets must cooperate in refusing to lend to a debtor in default. The more potential lenders are expected to boycott an errant debtor, the greater the debtor's incentive to maintain debt service. In this sense, cooperation among financial institutions to monitor and enforce foreign debt contracts is crucial, and the benefits of such sanctions to each creditor rise dramatically with the scale of the cooperative effort. ${ }^{23}$

23. This would, in fact, be a good example of Hirshleifer's weakest link sort of public good: the strength of the creditor position is dependent on the contribution (i.e., willingness to deny credit) 
There are many obstacles to collective action among creditors. Their numbers are often large and credit is undifferentiated, to name but two. However, financial institutions tend to have many connections among themselves, from correspondent banking to joint ventures, so that their reputations with each other may be important. This will conduce to cooperation.

In the case of foreign lending, then, I expect the use of force by home countries against debtors in default to be relatively rare. However, I expect to find a great deal of cooperation among creditors, for the benefits of creditor unity are large. Collaboration also will depend on circumstances that affect the costs of collective action, such as how close the ties among the creditors are along other dimensions.

To summarize, I expect foreign investment in primary production for export to be most closely associated with the unilateral use of force by the home country. I expect public utilities to be less tied to the use of force, although characterized by home-country unilateralism. Foreign loans should seldom be linked to military intervention, and I expect home governments to be relatively cooperative. Multinational manufacturing affiliates are unlikely to be seized by force and are therefore unlikely to become the focus of violent disputes and unlikely to lead to home-country cooperation.

It will be noted that these four types of investments cover several possibilities in my two dimensions of dependent variable variation. Their characterization is nonetheless schematic and partial and not meant to cover all eventualities.

These analytical expectations do, nonetheless, lead to some straightforward predictions about the relationship between colonialism and different forms of foreign investment. I expect colonial rule to be most commonly found in association with foreign investment whose problems can be resolved most easily by unilateral intervention, for colonialism is unilateral and interventionist. Thus, I expect colonialism to be especially strongly associated, not with foreign investments in general, but rather with foreign investments in primary production.

It is important that empirical evidence for the argument presented above involves a correlation between certain forms of political governance and certain types of investments, such as between colonialism and investment in primary production, but does not imply any particular chronology. An appropriate analogy is corporate governance. The argument that vertical integration is the most effective corporate form for the automobile industry (due to high levels of asset specificity) does not necessarily imply that automotive firms choose vertical integration consciously, only that vertically integrated firms are more likely to be found in the automotive sector than in a sector not so characterized by asset specificity. 
The point is that the most cost-effective way to monitor and enforce cross-border investments varies with the type of investment. This implies, for example, both that primary investors will be more likely to support colonial annexation and that colonial possessions are more likely to attract a disproportionate amount of primary investment. If primary investments in the developing world are safer in colonial regions than elsewhere, we expect such investments outside colonial control to either wither or press for annexation, and we expect investors in such sectors to gravitate toward colonies. Presumably, of course, in practice there is a chronological or even causal relationship; but for my argument, which came first is not particularly important.

\section{Colonialism and investment}

\section{Evidence from the British Empire}

The analytical considerations presented above lead, most concretely, to hypotheses correlating colonialism with foreign investment in primary production. Although it is theoretically possible to evaluate the other hypotheses presented above, such as the likelihood that foreign lending is associated with private lender cooperation but not military intervention, colonialism is the most easily measured outcome. It is to an evaluation of this claim that I now turn. $^{24}$

It is not easy to bring statistical and historical evidence to bear on the relationships of interest here. The data on foreign investment often are unreliable, and the categories are seldom comparable. Investigations of the politics of foreign investments are often cursory or stylized. Many episodes of potential relevance have not been explored by historians. Within these strictures, all I can do is attempt to use those data and case studies available.

The most straightforward way to weigh my approach is to see whether colonial control is correlated with the investments I anticipate will be associated with the use of force and home country unilateralism. Some data along these lines are available for the United Kingdom. However, almost no analogous data are available for other European colonial experiences. Hence, my statistical analysis is confined to the British case.

It is worth starting with some consideration of evidence that colonialism could and did affect the composition of foreign investment in the colonial area. Although this is a controversial topic, one study shows that investors from the colonial powers systematically were overrepresented in foreign direct investments in their colonies-in 1938 by a factor of 2.2 for British colonies and 11.9

24. Since measurement of other possible outcomes is much more controversial (and may not even be possible), I restrict myself to the analysis of colonialism alone. Although this issue is most relevant to historical debates on the economic theory of imperialism, restricting my evaluation is somewhat arbitrary, done for reasons of simplicity and feasibility. 
for French colonies. ${ }^{25}$ That is, there was 2.2 times as much investment by British investors in British colonies as would have been predicted given Britain's share of total global investment and 11.9 times as much French investment in French colonies. Another study by the same scholar indicates that British direct investment in British colonies earned higher rates of return than British investment in non-British developing regions. ${ }^{26}$ This dovetails with the general revival among historians of the view that economic motives played a role in colonial expansion, albeit not in the simple way posited by earlier critics. $^{27}$

Recently compiled quantitative evidence can be used more directly to assess my argument about the political implications of different sorts of foreign investments. Tables 1-5 present some of this evidence, arrayed to highlight the sectoral composition of British investment inside and outside the British Empire. Table 1 looks at British overseas investments from 1865 to 1914 in all areas, developed and developing, differentiated as to whether the host region was subject to British sovereignty. Investment in transport, manufacturing, and public utilities was overrepresented outside the empire, while investment in primary production was overrepresented inside the empire. Overrepresentation in this context means that a larger proportion of British investment in the region was of this particular type compared with overall British foreign investment; or, stated another way, that more of this type of investment was made in the region than would be expected given the region's overall share of total British foreign investment. For example, looking at Table 1, primary investment made up 16.5 percent of British investment inside the empire but only 11.9 percent of British investment outside the empire. By this criterion, colonial areas had proportionally greater shares of investment in primary

25. Peter Svedberg "Colonial Enforcement of Foreign Direct Investment," The Manchester School of Economic and Social Studies 26 (March 1981), pp. 21-38. Svedberg notes especially the tendency of the metropolitan powers to discourage or prohibit investment in extractive industries in their colonies (p. 22).

26. Peter Svedberg, "The Profitability of U.K. Foreign Direct Investment Under Colonialism," Joumal of Development Economics 11 (December 1982), pp. 273-86. On the other hand, Davis and Huttenback argue that except at the outset of their period of study (1860-1912), rates of return were not substantially higher inside the British Empire than elsewhere. See Lance Davis and Robert Huttenback, Mammon and the Pursuit of Empire: The Political Economy of British Imperialism, 1860-1912 (Cambridge: Cambridge University Press, 1986), chap. 3. Edelstein finds a higher overseas rate of return than at home in Great Britain. See Michael Edelstein, Overseas Investment in the Age of High Imperialism (New York: Columbia University Press, 1982), pp. 111-59. The issue is important, of course, but does not directly impinge on my argument. No existing study breaks down the data as would be necessary to evaluate my argument (by form of rule and sector at comparable levels of development).

27. The work of P. J. Cain and A. G. Hopkins is paramount in this reassessment. Cain surveys recent work on the British case in P. J. Cain, Economic Foundations of British Overseas Expansion 1875-1914 (London: Macmillan, 1980). Hopkin's masterly application to West Africa is in A. G. Hopkins, An Economic History of West Africa (New York: Columbia University Press, 1973), chaps. 4 and 5. For a summary of their views and an outstanding history of the British experience, see P. J. Cain and A. G. Hopkins, British Imperialism, 2 vols. (London: Longman, 1993). 
TABLE 1. British overseas investment, 1865-1914, by sector and form of government ${ }^{\mathrm{a}}$

\begin{tabular}{|c|c|c|c|c|c|c|}
\hline Sector & $\begin{array}{c}\text { Total } \\
\text { investment }\end{array}$ & $\begin{array}{c}\text { Percentage } \\
\text { of total }\end{array}$ & $\begin{array}{c}\text { Foreign } \\
\text { (nonempire) } \\
\text { investment }\end{array}$ & $\begin{array}{c}\text { Percentage } \\
\text { of total }\end{array}$ & $\begin{array}{c}\text { Empire } \\
\text { investment }\end{array}$ & $\begin{array}{l}\text { Percentage } \\
\text { of total } \\
\text { investmen }\end{array}$ \\
\hline Government loans & $1,320.6^{b}$ & 41.9 & 656.3 & 33.9 & 664.3 & 54.4 \\
\hline Transport $^{c}$ & $1,199.3$ & 38.0 & 904.2 & 46.8 & 295.1 & 24.2 \\
\hline Primary ${ }^{d}$ & 431.4 & 13.7 & 230.2 & 11.9 & 201.2 & 16.5 \\
\hline Manufacturing & 84.0 & 2.7 & 61.1 & 3.2 & 22.9 & 1.9 \\
\hline Public utilities & 93.3 & 3.0 & 67.1 & 3.5 & 26.2 & 2.1 \\
\hline Trade and services & 26.7 & 0.9 & 15.1 & 0.8 & 11.6 & 0.9 \\
\hline Totale & $3,155.3$ & 100.0 & $1,934.0$ & 100.0 & $1,221.3$ & 100.0 \\
\hline
\end{tabular}

2Figures exclude the very small amounts for which the sector is unknown. For definitions and other details, see Davis and Huttenback, Mammon and the Pursuit of Empire.

${ }^{b}$ Monetary figures are in millions of pounds sterling.

Transport is almost exclusively railroads.

dPrimary is agriculture and extractive plus financial, land, and investment companies (which Largely invested in properties with development potential in the primary sectors).

cPercentage totals may not add to 100 due to rounding.

Source. Calculated from Lance Davis and Robert Huttenback, Mammon and the Pursuit of Empire: The Political Economy of British Imperialism, 1860-1912 (Cambridge: Cambridge University Press, 1.986), p. 59.

production, while independent areas had greater shares of investment in utilities (including railroads) and manufacturing. Data on government loans run counter to my expectations, which are discussed below. (British gross national product in the 1890 s was approximately $£ 1.7$ billion, so the amounts involved were very substantial by contemporary standards.)

Tables 2 and 3 present data for the various types of developing regions, so as to avoid comparing areas at strikingly different stages of growth, for it could easily be argued that the differences between foreign investment in Kenya and the United States, say, are more easily attributed to level of development than to form of rule. Table 2 indicates the sectoral breakdown of British investment in each of the three types of less developed area (LDA). Government lending is disproportionately concentrated in the developing empire, which is a problem for my approach. However, for the less developed empire as a whole, the relative preponderance of primary investments is clear: 46.9 percent of private-sector British investment (i.e., excluding loans to governments) in the empire went to primary activities, while 23.7 percent of British investment in the private sector in nonempire developing areas went to such agricultural and extractive investments. By the same token, transport (overwhelmingly rail- 
TABLE 2. British overseas investment in less developed areas (LDAs), $1865-1914$, by sector

\begin{tabular}{|c|c|c|c|c|}
\hline & \multicolumn{4}{|c|}{ Type of $L D A^{4}$} \\
\hline & Foreign ${ }^{b}$ & Empire & Dependent ${ }^{d}$ & All \\
\hline Total investment ${ }^{\mathrm{c}}$ & 909.5 & 485.0 & 114.4 & 1.394 .5 \\
\hline $\begin{array}{l}\text { Loans to governmentsf } \\
\text { (\% of total) }\end{array}$ & $\begin{array}{l}369.6 \\
(43.6)\end{array}$ & $\begin{array}{l}260.1 \\
(53.6)\end{array}$ & $\begin{array}{c}30.9 \\
(27.0)\end{array}$ & $\begin{array}{l}657.0 \\
(47.1)\end{array}$ \\
\hline Total private investment & 512.6 & 224.9 & 83.5 & 737.5 \\
\hline $\begin{array}{l}\text { Transports } \\
\text { (\% of private investment) }\end{array}$ & $\begin{array}{l}349.4 \\
(68.2)\end{array}$ & $\begin{array}{c}94.5 \\
(42.0)\end{array}$ & $\begin{array}{c}14.8 \\
(17.7)\end{array}$ & $\begin{array}{l}443.9 \\
(60.2)\end{array}$ \\
\hline $\begin{array}{l}\text { Primaryh } \\
\text { (\% of private investment) }\end{array}$ & $\begin{array}{l}121.5 \\
(23.7)\end{array}$ & $\begin{array}{l}105.5 \\
(46.9)\end{array}$ & $\begin{array}{c}61.8 \\
(74.0)\end{array}$ & $\begin{array}{l}227.0 \\
(30.8)\end{array}$ \\
\hline $\begin{array}{l}\text { Manufacturing } \\
\text { (\% of private investment) }\end{array}$ & $\begin{array}{l}12.5 \\
(2.4)\end{array}$ & $\begin{array}{c}5.8 \\
(2.6)\end{array}$ & $\begin{array}{c}0.9 \\
(1.1)\end{array}$ & $\begin{array}{l}18.3 \\
(2.5)\end{array}$ \\
\hline $\begin{array}{l}\text { Public utilities } \\
\text { (\% of private investment) }\end{array}$ & $\begin{array}{l}23.4 \\
(4.6)\end{array}$ & $\begin{array}{l}11.7 \\
(5.2)\end{array}$ & $\begin{array}{l}5.0 \\
(6.0)\end{array}$ & $\begin{array}{l}35.1 \\
(4.8)\end{array}$ \\
\hline $\begin{array}{l}\text { Trade and services } \\
\text { (\% of private investment) }\end{array}$ & $\begin{array}{c}5.8 \\
(1.1)\end{array}$ & $\begin{array}{c}7.4 \\
(3.3)\end{array}$ & $\begin{array}{l}1.0 \\
(1.2)\end{array}$ & $\begin{array}{l}13.2 \\
(1.8)\end{array}$ \\
\hline
\end{tabular}

${ }^{a}$ Figures exclude the very small amounts for which the sector is unknown. Chi-square with Foreign LDAs, Empire LDAs, and Dependent LDAs $=112.49$ with $8 \mathrm{df}$. Chi square with Foreign and Empire LDAs $=49.12$ with 4 d.f. In both cases the null bypothesis that investment is independent of form of governance is rejected at well above the 99 percent confidence level.

bDeveloping areas are Africa, Asia, Latin America, and the Pacific.

¿Australia, Canada, and New Zealand are excluded.

India and South Africa are excluded from this subcategory of LDAs within the British Empire.

En millions of pounds sterling.

tPercentage total may not add to 100 due to rounding.

eThis category comprises railroads almost exclusively.

"This category comprises agricultural and extractive industries plus financial, land, and investment companies (which largely invested in properties with development potential in the primary sectors).

Source. Calculated from Lance Davis and Robert Huttenback, Mammon and the Pursuit of Empire: The Political Economy of British Imperialism, 1860-1912 (Cambridge: Cambridge Utniversity Press, 1986), pp. 64-67.

roads) comprised 42.0 percent of all British private-sector investment in the developing empire but 68.2 percent outside it. Again, in the terms used above, there is a clear overrepresentation of (that is, bias toward) primary investment, and a clear underrepresentation of (that is, bias against) transport investment, inside the empire. The other categories are largely indeterminate.

The dependent developing areas, that is the developing empire without India and South Africa, tend to confirm my expectations even more strongly. Loans 


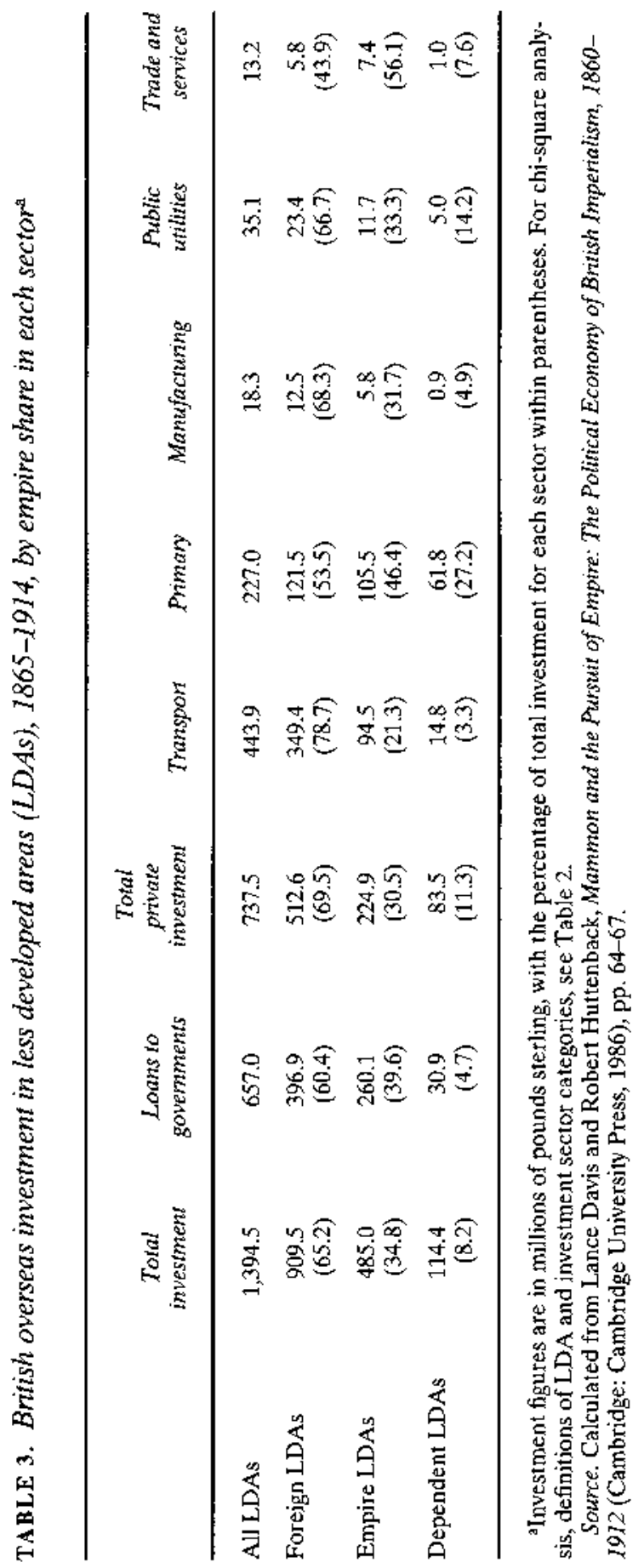


TABLE 4. British investment in Latin America in 1913, by sector

\begin{tabular}{|c|c|c|}
\hline Sector & $\begin{array}{l}\text { Millions of } \\
\text { pounds sterling }\end{array}$ & Percentage \\
\hline Government loans & 445.5 & 37.8 \\
\hline Railroads & 404.5 & 34.3 \\
\hline Raw materials ${ }^{a}$ & 97.8 & 8.3 \\
\hline Industrial and miscellaneous & 37.4 & 3.2 \\
\hline Public utilities ${ }^{b}$ & 157.3 & 13.3 \\
\hline Financial & 37.4 & 3.2 \\
\hline Totak & $1,179.9$ & 100.0 \\
\hline
\end{tabular}

\footnotetext{
Includes financial, land, and investment companies (which largely invested in properties associated with raw materials production).

'Includes shipping.

'Percentage total does not add to 100 due to rounding.

Source. Calculated from Irving Stone, "British Direct and Portfolio Investment in Latin America before 1914,"Joumal of Economic History 37 (September 1977).
}

to governments comprise only 27 percent of British investment in these regions. Of private-sector investment in the dependent colonies, primary production accounted for an enormous 74 percent of the total. This is a very substantial overrepresentation of (that is, bias toward) primary investment in the dependent empire. Public utilities are slightly overrepresented, while manufacturing and transport are underrepresented. In fact, taken as a whole and expressed slightly differently than in Table 2 , government loans, railroads, manufacturing, and utilities combined made up 45 percent of British investment in the dependent colonies, compared with 86 percent in noncolonial LDAs.

The data are turned around in Table 3 , so that instead of displaying the sectoral breakdown of empire investment, they indicate the empire share of each sector's investment. For example, looking at column 3, foreign LDAs accounted for 69.5 percent of all British private investment (excluding government loans) in all the LDAs, while empire LDAs accounted for 30.5 percent and dependent LDAs (a subset of empire LDAs), for 11.3 percent of the total private investment. However, looking at the column for primary investment, 53.5 percent of all British private primary investment in all LDAs went outside the empire; 46.4 percent inside the empire, and 27.2 percent to dependent colonies. This table, like the previous one, shows the heavy concentration of primary investment in the empire and especially in the dependent colonies. In other words, while the dependent colonies accounted for just 11.3 percent of all British private investment in the developing world, they took 27.2 percent of all primary investment. Simple statistical analyses 
(presented in the notes to Table 2) demonstrate that this relationship is not merely coincidental: indeed, we can reject the possibility that the relationship between empire and nonempire investment and their sectoral composition is casual at well above the 99 percent confidence level.

The overrepresentation of extractive and agricultural investments in the dependent colonial areas is striking and tends to confirm my hypothesis about the correlation between colonialism and primary investment. Indeed, these data led Lance Davis and Robert Huttenback, the authors of the study on which Tables 1-3 are based, to observe, "It appears that in the dependent colonies, finance imperialism, to the degree that it existed, was intimately connected to the possession of land and a legal structure that gave British investors the right to relatively unfettered exercise of their ownership privi[eges." "28

Table 4, from another source, presents a sectoral breakdown of British investment in Latin America in 1913. The relevant colonial comparisons to the data in this table are either the "empire LDAs" or "dependent colonies" entries in Tables 2 and 3. The data in Table 4 indicate, again as expected and in many ways contrary to received wisdom, that in these independent countries raw materials investments were quite insignificant, while British investments were concentrated in government loans, railroads, and utilities.

Table 5, from yet another study, presents data from the interwar era. During this period colonial governments clearly borrowed substantially more than independent states; the proximate reason was that the British government restricted borrowing by nonsterling areas in order to defend the pound. ${ }^{29}$ Looking at private investment alone, we continue to see a substantial colonial preference for primary production and a foreign preference for utilities and railroads. Oil is treated separately here, since much British oil investment was in areas under semiformal British control (such as League of Nations mandates).

Although there are many problems with the statistical data at our disposal, they do indicate the systematic bias expected by my analysis. That is, colonialism was strongly associated with foreign investment in primary production. It is not possible to determine from these data which way the causal arrow may have run, for time series are sorely inadequate. Only qualitative evidence, if that, can help clarify the direction of causation in particular cases. Nonetheless, it does appear that British overseas investment in manufacturing and utilities was correlated with independent status and investment in primary production, with colonial rule.

28. Davis and Huttenback, Mammon and the Pursuit of Empire, p. 62.

29. For details, some of which are discussed below, see John Michael A.tkin, British Overseas Investment 1918-1931 (New York: Arno Press, 1977); and John Atkin, "Oficial Regulation of British Overseas Investment, 1914-1931," Economic History Review 23 (August 1970), pp. 324-35. 
TABLE 5. British overseas investment, 1918-31, by sector and form of government, in millions of pounds sterling and percentages ${ }^{\mathrm{a}}$

\begin{tabular}{|c|c|c|c|c|c|c|}
\hline \multirow[b]{2}{*}{ Sector } & \multicolumn{6}{|c|}{ Form of government } \\
\hline & Total & $\begin{array}{l}\text { Percentage } \\
\text { of total }\end{array}$ & $\begin{array}{l}\text { Independent } \\
\text { states }\end{array}$ & $\begin{array}{c}\text { Percentage } \\
\text { of total }\end{array}$ & $\begin{array}{l}\text { Colonial } \\
\text { nde }\end{array}$ & $\begin{array}{c}\text { Percentage } \\
\text { of total }\end{array}$ \\
\hline \multicolumn{7}{|l|}{ All investment } \\
\hline Government & 802.6 & 61.8 & 211.1. & 47.0 & 591.5 & 69.6 \\
\hline Private & 496.3 & 38.2 & 237.5 & 52.9 & 258.7 & 30.4 \\
\hline Total & $1,298.9$ & 100.0 & 448.7 & 100.0 & 850.2 & 100.0 \\
\hline \multicolumn{7}{|l|}{ Private investment } \\
\hline Railtroads & 96.3 & 19.4 & 60.2 & 25.3 & 36.1 & 14.0 \\
\hline Primaty & 152.3 & 30.7 & 36.9 & 15.5 & 115.4 & 44.6 \\
\hline Oil & 70.5 & 14.2 & 55.4 & 23.3 & 15.1 & 5.8 \\
\hline $\begin{array}{l}\text { Commercial and } \\
\text { industrial }\end{array}$ & 75.0 & 15.1 & 34.9 & 14.7 & 40.1 & 15.5 \\
\hline Public utilities ${ }^{c}$ & 47.9 & 9.7 & 31.1 & 13.1 & 16.8 & 6.5 \\
\hline Financial & 54.3 & 10.9 & 19.1 & 8.0 & 35.2 & 13.6 \\
\hline Total & 496.3 & 100.0 & 237.5 & 100.0 & 258.7 & 100.0 \\
\hline
\end{tabular}

aPercentage totals may not add to 100 due to rounding.

'Includes agriculture and extractive industries, plus financial, land, and investment companies (which latgely invested in properties with development potential in the primary sectors) but excludes oil.

Includes shipping.

Source. John Michael Atkin, British Overseas Investment 1918-1931 (New York: Arno Press, 1977), p. 130.

\section{Other evidence}

Quantitative evidence on the British case, which is suggestive but hardly conclusive, can be supplemented with other evidence, especially that based on historical case or country studies. It is useful to discuss this by sector, to parallel the analytical predictions presented above. Of course, this information is at best impressionistic.

Primary production for export. The approach described herein leads to an expectation that primary investment will be correlated with the use of force by home countries and with a relative lack of cooperation among investors. In many historical episodes, indeed, primary investors were at the forefront of 
interventionist agitation; additionally, primary investment is substantially overrepresented in virtually every colonial setting. The role of mining in sub-Saharan Africa, from the Congo to the cape, is frequently remarked upon.$^{30}$ So, too, are the colonialist proclivities of those involved in plantation agriculture in East Africa, the Indian subcontinent, and Southeast Asia. ${ }^{31}$ Again, whether the prior existence of primary investments gave rise to demands for annexation or prior colonial control made the area attractive to primary investors is immaterial for the theory presented here-my argument is about the affinity of a form of investment for a form of political governance..$^{32}$

The interventionist tendencies of the oil industry in the decades before the Organization of Petroleum Exporting Countries (OPEC) was formed are well-known. Evidence about the degree of cooperation among oil investors is less clear-cut. In some instances, oil companies procured and secured exclusive access to particular territories: especially within the colonial empires, rights to mine oil often were reserved explicitly or implicitly for metropolitan firms. ${ }^{33}$ However, in other instances, oil firms cooperated in the joint exploitation of the resource and presented a united front to local rulers. This was true in parts of the Middle East: the Red Line Agreement of 1928, for example, reserved much of the former Ottoman Empire for a few Anglo-Dutch, British, French, and U.S. firms. Cooperation was repeated elsewhere, as in conflict between oil producers and a nationalist Iranian regime in the early $1950 \mathrm{~s}^{34}$ Cooperation among oil investors-rare among other primary investors-was a function of

30. For some examples, see John S. Galbraith, Crown and Charter: The Early Years of the British South Africa Company (Berkeley: University of Califotnia Press, 1974); Robert Kubicek, Economic Imperialism in Theory and Practice: The Case of South African Gold Mining Finance 1886-1914 (Durham, N.C.: Duke University Press, 1979); and A. Atmote and S. Marks, "The Imperial Factor in South Africa in the Nineteenth Century," in E. F. Penrose, ed., European Imperialism and the Partition of Africa (London: Frank Cass, 1975), pp. 105-39. The case of Cecil Rhodes has attracted. an enormous amount of recent attention. See Arthur Keppel-Iones, Rhodes and Rhodesia: The White Conquest of Zimbabwe 1884-1902 (Kingston, Ontario: McGill-Queen's University Press, 1983); Rob Turrell, "Rhodes, De Beers, and Monopoly, ${ }_{1}$ Joumal of Imperial and Commonwealth History 10 (May 1982), pp. 311-43; S. D. Chapman, "Rhodes and the City of London: Another View of Imperialism," Histonical Joumal 28 (September 1985), pp. 647-66; Robert Vicat Turrell, "Finance... The Governor of the Imperial Engine': Hobson and the Case of Rothschild and Rhodes," Joumal of Southem African Sudies 13 (April 1987), pp. 417-432; and Robert Vicat Turrell and Jean-Jacques Van Helten, "The Rothschilds, the Exploration Company, and Mining Finance," Business History 28 (April 1986), pp. 181-205.

31. For a lucid treatment of agriculture in Kenya, see Richard D. Wolft, The Economics of Colonialism: Britain and Kenya, 1870-1930 (New Haven, Conn.: Yale University Press, 1974). In his An Economic History of West Africa, Hopkins sets out a clear model of the colonial economy and applies it to the West African case. Colonies (such as Kenya) in which metropolitan settler agticulture was impottant may be seen as a special, perhaps extreme, case. For a fascinating treatment, see Ian Lustick, State-building Failure in British lreland and French Algeria (Betkeley, Calif.: Institute of International Studies, 1985).

32. For a strongly contradictory argument, see Stephen D. Krasner, Defending the National Interest: Raw Materials Investments and U.S. Foreign Policy (Princeton, N.J.: Princeton University Press, 1978).

33. For a case study, see Marian Kent, Oit and Empire: British Policy and Mesopotamian Oil, 1900-1920 (London: Macmillan, 1976).

34. For a summary of the conflict, see Krasner, Defending the National Interest, pp. 119-28. 
the very small number of global oil companies and their dense and longstanding networks of economic and other linkages. As more independent producers arose, cooperation among oil investors gradually eroded, although the private cartel was largely replaced by OPEC's cartel of governments.

The overrepresentation of British primary investment in the colonies was noted above. Although similarly well-developed statistics are not available for other colonial powers, what evidence there is reinforces the impression of the British data. Some 42 percent of investment in French West Africa was in primary production; most of the rest ( 39 percent) was in commercial services, an important category that we ignore here. ${ }^{35}$ Over three-quarters of the Belgian investment in the Congo apparently was in mines and the railways connected directly to them. ${ }^{36}$ Japan's overseas investment before World War II was concentrated in China and its colonies. Assets in Japan's possessions-Korea, Kwantung, Taiwan, and the South Pacific-were concentrated almost exclusively in agriculture and raw materials production. It also may not be coincidental that Japanese investment in Manchuria, where Japanese political influence (later direct rule) was strongest, was concentrated in primary production, while investments in other parts of China were more diversified and included many manufacturing firms. ${ }^{37}$

A particularly interesting and a difficult case to explain is that of American overseas investors. Elsewhere I have attempted to show that those most prone to demand U.S. government intervention in Latin America were primary investors. Indeed, many U.S. overseas lenders and manufacturing multinational corporations opposed gunboat diplomacy, and as U.S. investment in the

35. See p. 654 of David K. Fieldhouse, "The Economic Exploitation of Africa," in Ptosser Gifford and William Roger Louis, eds., France and Britain in Africa (New Haven, Conn.: Yale University Press, 1971), pp. 593-662. For excellent discussions of the role of trade, see Hopkins, $A n$ Economic History of West Africa; C. W. Newbury, "The Tariff Factor in Anglo-French West African Partition," in Gifford and Louis, France and Britain in Africa, pp. 220-59; C. C. Wrigley, "Neo-mercantile Policies and the New Imperialism," in Clive Dewey and A. G. Hopkins, eds., The Imperial Impact (London: Athlone Press, 1978), pp. 20-34; and Barrie Ratcliffe, "Commerce and Empire: Manchester Merchants and West Africa, 1873-1895," Joumal of Imperiat and Commonwealth Histony 8 (May 1979), pp. 293-320. Note that "trade" does not involve exports and imports in and of themselves but only the wholesale and retail commetcial sectors. For evidence about the French experience, such as that bankers supported cooperation in China, Morocco, and the Ottoman Empire while mining interests wanted a Moroccan ptotectotate and more exclusive policies elsewhere, see C. M. Andrew and A. S. Kanya-Forstner, "French Business and the French Colonialists," Histonical Joumal 19, No. 4 (December 1976), pp. 981-1000.

36. S. Herbert Frankel, Capital Investment in Africa (London: Oxford University Press, 1938), pp. 167 and 204.

37. Most Japanese-owned industrial enterprises operating in the colonies and Manchuria were related directly to primary production; they were, for example, sugar refineries or iron and steel plants. See especially Peter Duus, "Economic Dimensions of Meiji Impetialism: The Case of Korea, 1895-1910," Mark Peattie, "The Nan'yo: Japan in the South Pacific, 1885-1945," and Samuel Pao-San Ho, "Colonialism and Development: Korea, Taiwan, and Kwantung," all in Ramon Myers and Mark Peattie, eds., The Japanese Colonial Empire, 1895-1945 (Princeton, N.J.: Princeton University Ptess, 1984), pp. 128-71, 172-210, and 347-398, respectively; and Mira Wilkins, "Japanese Multinational Enterprise before 1914," Business History Review 60 (Summer 1986), pp. 199-231. 
region diversified toward government lending and manufacturing, demands for intervention subsided, as did intervention itself. ${ }^{38}$

Affliates of multinational manufacturing corporations. I expect that manufacturing investment will not be strongly associated with the use of force (i.e., with colonial control); nor will it see much cooperation among investors. On the use of force, recent nationalist ambivalence about manufacturing multinational corporations has obscured prior historical experience. Indeed, in interwar South America it was common to distinguish between "bad" foreign direct investments in primary production and railroads (which were mostly British) and "good" foreign investments in manufacturing (which were mostly American). ${ }^{39}$ Parallel phenomena have been noted in many societies in the process of decolonization: the end of colonial rule is associated with a relative decline in foreign investment in primary production and a significant rise in the share of foreign investment going into manufacturing industries.$^{40}$ One student of British manufacturing investment abroad, John Stopford, has remarked that "the early manufacturing investments were made without regard to the existence of the Empire, [while] investments by British manufacturers to control sources of raw materials for their own factories were distinctly biased towards Empire sources." "41

The Indian experience is interesting in this regard. After World War I the colonial government secured substantial economic policy autonomy, and as this took place foreign investment in manufacturing rose continually (in part, due to increased Indian tariffs) ${ }^{42}$ The leading scholar of the economics of Indian decolonization draws a direct connection between the increasing likelihood of independence and the growth of foreign interest in local manufacturing (and the relative decline of primary investments). ${ }^{43}$ It should be recalled that for my purposes the chronology is not important: I argue simply that foreign

38. Frieden, "The Economics of Intervention."

39. See, for example, Catlos Diaz Alejandro, Essays in the Economic History of the Argentine Republic (New Haven, Conn: Yale University Press, 1970), p. 32.

40. For a fascinating case study, see David $\mathrm{K}$. Fieldhouse, Unilever Overseas (London: Croom Helm, 1978). See also D. K. Fieldhouse, " 'A New Imperial Systern'? The Rise of Multinational Corporations Reconsidered," in Wolfgang Mommsen and Jurgen Osterhammel, eds., Imperialism and After (London: Allen and Unwin, 1986), pp. 225-40; and the comparisons in Miles Kahler, "Political Regime and Economic Actors: The Response of Firms to the End of Colonial Rule," World Politics 33 (April 1981), pp. 383-412.

41. The quotation is from p. 323 of John Stopford, "The Origins of British-based Multinational Manufacturing Enterptises, ${ }^{12}$ Busimess History Review 48 (Autumn 1974), pp. 303-35.

42. B. R. Tomlinson, "Foreign Private Investment in India 1920-1950," Modem Asian Studies 12 (October 1978), pp. 655-77. Although investment in manufacturing was increasing, within the category of private investment (i.e., excluding government lending), investment in primary production remained predominant: it comprised over 39 percent of all British investment in private enterprise in India. See B. R. Tomlinson. The Political Economy of the Raj 1914-1947: The Economics of Decolonization in India (London: Macmillan, 1979), p. 49.

43. Tomlinson, The Political Economy of the Raj 1914-1947, pp. 47-51. In chapter 5 of that work, Tomlinson uses Hopkins's model of the colonial economy to argue that the decay of the economic foundations of colonialism in India made independence a near cettainty. 
investment in manufacturing is less dependent upon colonial ties than is investment in primary production, and the Indian experience appears to confirm this.

A statistical study of "forced divestment" in the less-developed countries (LDCs) between 1960 and 1976 also lends credence to my hypotheses. The data indicate that while the agricultural and extractive industries accounted for 15 percent of total foreign direct investment in the LDCs, they accounted for 41 percent of the acts of expropriation; foreign-owned manufacturing affiliates made up 41 percent of investment and 27 percent of expropriations. Within the manufacturing sector, a few industries characterized by standardized technologies (and, thus, less firm-specific rents) -food; beverages; tobacco, leather and footwear; and cement, stone, and clay-accounted for only 15 percent of all manufacturing foreign direct investment but fully 38 percent of all manufacturing expropriations. ${ }^{44}$

Another statistical study used a different sample but reached similar results. While investments in primary production accounted for 18.7 percent of all foreign investment in the developing world in 1967, they accounted for 37.4 percent of all assets nationalized between 1956 and 1972. Utilities comprised 6.6 percent of all investment but 16.8 percent of all nationalized assets. Manufacturing foreign direct investment comprised 28.4 percent of the 1967 total but just 16.2 percent of all assets nationalized between 1956 and $1972 .{ }^{45}$

Additionally, rarely have manufacturing multinational corporations attempted to bring their home governments into conflict with host countries (such spectacular cases as ITT in Chile are clearly exceptions). Nor have manufacturing investors commonly cooperated with each other in their dealings with host countries. The general rule, as expected, is direct firm-to-hostgovernment bargaining and sometimes private or quasi-public insurance schemes. ${ }^{46}$

44. If five countries (of seventy-six) in the sample that engaged in blanket expropriations are excluded the bias is even more evident; among the most selective "takers," 59 percent of all expropriations are in the extractive sectors. The data can be found on pp. 76, 77, and 80-81 of Stephen Kobrin, "Foreign Entetprise and Forced Divestment in the LDCs," Intemational Organization 34 (Winter 1980), pp. 65-88. Kobrin's study is formulated with the sorts of variables I consider explicitly (along with several others). See also David Jodice, "Sources of Change in Third World regimes for foreign direct investment, 1968-1976," Intemational Organization 34 (Spring 1980), pp. 177-206.

45. M. L. Williams, "The Extent and Significance of the Nationalization of Foreign-Owned Assets in Developing Countries, 1956-1972," Oxford Economic Papers 27 (July 1975), pp. 260-73. The author treats oil separately and shows that it is disproportionately not nationalized. Presumably, if the time period were brought up to 1975 , this would be strikingly different since between 1972 and 1975 the bulk of foreign oil investments in the LDCs were, in fact, nationalized.

46. For case studies of the former, see Douglas Bennett and Kenneth Sharpe, Transnational Comporations Versus the State: The Political Economy of the Mexican Auto Industry (Princeton, N.J.: Princeton University Press, 1985); Gary Gereffi, The Phamaceutical Industry and Dependency in the Third World (Princeton, N.J.: Princeton University Ptess, 1983); and the essays in Richard Newfatmer, ed., Profits, Progress, and Poverty: Case Studies of International Industries in Latin America (Notre Dame, Ind.: University of Notre Dame Ptess, 1985). On. Ametican overseas investment insurance, see Lipson, Standing Guard, chap. 7. 
Public utilities. My approach leads to the expectation that, although host governments might appropriate a utility, home governments are not likely to use force to defend it and cooperation among utility investors will be difficult (because the benefits are limited and the costs, high). By far the most historically important type of utility in which foreign investment was significant is the railroad. The data in Tables $1-5$ indicate that British railroad and utilities investment was heavily biased toward independent states, and historical evidence does not provide any obvious case of military intervention in defense of either a utility or a railroad.

Cooperation among utilities investors, especially railroad investors, was also very fragile. The spectacular divisions among Western nations over railroad development in Africa and the Near East-the Berlin to Baghdad, cape to Cairo, and trans-Saharan routes all became real or potential sources of conflict-are well-known. ${ }^{47}$ Strife was not due to lack of attempts to cooperate. Joint railroad ventures, typically to finance the development of new lines with loans from several national financial centers, were tried in China and the Ottoman Empire but with little success. ${ }^{48}$ Even where investors all were British, with similar interests - as in negotiations with the Argentine government over railroad guarantees in the $1890 \mathrm{~s}$-cooperation was almost impossible to sustain. ${ }^{49}$

Private loans to governments. The argument presented here, namely, that foreign loans to governments will tend not to be associated with home-country use of force and will tend to be associated with cooperation among home countries, is perhaps the most divergent from traditional impressions and received wisdom. The logic, nonetheless, is clear. A loan is a promise, and if unmet it cannot be seized by force. The principal penalty available to creditors against an errant debtor is to deny it the ability to borrow again; in this case, enforcement depends almost entirely upon cooperation among potential international lenders.

47. A general overview of railroad conflict can be found in Winfried Baumgart, Imperialism (Oxford: Oxford University Press, 1982), pp. 25-32. On the well-known Baghdad Railway case, see, for example, the essays in Matian Kent, ed., The Great Powers and the End of the Ottoman Empire (London: George Allen and Unwin, 1984). For an interesting perspective on the Near East, see David Mclean, "British Finance and Foreign Policy in Tutkey: The Smyrna-Aidin Railway Settlement, 1913-1914," Historical Joumal 19 (June 1976).

48. On the Chinese experience, especially the American attempts to gain entry to the railroad competition, see Michael Hunt, The Making of a Special Relationship (New York: Columbia University Ptess, 1983). An intriguing perspective on the relationship among diplomacy, finance, and Chinese railroads is discussed in Herbert Croly, Willard Straight (New York: Macmillan, 1925). Clarence Davis, in "Financing Imperialism: British and American Bankers as Vectors of Imperial Expansion in China, 1908-1920," Business History Review 56 (Summer 1982), pp. 236-64, emphasizes financial cooperation amidst conflict over the railroads. For a general overview of China, Turkey, and Persia, see David McLean, "Finance and 'Informal Empire' Before the First World War," Economic History Review 29 (May 1976), pp. 291-305.

49. Colin Lewis, British Raitways in Argentina 1857-1914: A Case Study of Foreign Investment, (London: Athlone, 1983), pp. 117-23. 
None of this is pure and simple. The use of force can help lenders, as it can help almost anyone. Although a home country might seize assets of a country in default, as mentioned above, such overseas assets of debtor nations are typically vastly outweighed by their liabilities. Creditors or their governments might seize income-earning property (such as a customs house) without the debtor government's consent, but this historically has been both extremely costly to accomplish and often useless. Nor is cooperation the only way of ensuring a return on foreign lending. Creditors use various mechanisms to cover default risk and can demand some sort of recoverable collateral from the debtor. ${ }^{50}$ However, my general argument still holds: relative to other investments, for international lenders the utility of military force is low and the gains from investor cooperation, high.

The myriad examples of creditor cooperation in dealings with debtors throughout history include the private creditor committees formed to monitor the finances of shaky LDA debtors during the century before World War I. Private financiers, generally with the support of their home governments, established such committees in Egypt, Greece, Morocco, Persia, Serbia, Tunisia, and elsewhere.

The Ottoman Public Debt Administration exemplifies this financial cooperation. In 1875, after fifteen years of borrowing, the Ottoman Empire began to default on its obligations. Six years later, after laborious negotiations among the empire, private bondholders' groups, and the European powers, the Decree of Mouharrem established a Public Debt Administration to be run by a Council of the Public Debt. The council had seven members: one representative of the British and Dutch bondholders, one representative apiece of the French, German, and Austro-Hungarian bank syndicates, an appointee of the Rome Chamber of Commerce, a representative of the Priority Bondholders appointed by the Anglo-French Ottoman Imperial Bank, and one representative of the Ottoman bondholders. ${ }^{51}$

By 1898 the Public Debt Administration controlled about one-quarter of all Ottoman government revenues; its mandate gradually had expanded to include responsibility for new bank loans and railroad guarantees. Certainly the administration's establishment and success owed much to the empire's impor-

50. There is an enormous literature on risk premia and credit rationing. For a survey, see Jonathan Eaton, Mark Gersovitz, and Joseph Stiglitz, "The Pure Theory of Country Risk," European Economic Review 30 (June 1986), pp. 481-513. The concept of "mutual hostage taking" in sovereign lending might be expanded to include some nineteenth-century practices, such as tying debt service to the income of a particular customs house or concession. Such a commitment, however, relied on the indebted sovereign's agreement. Medieval Eutope, in which the international financial carteI was poorly organized, provides purer examples of mutual hostage-taking in international lending. For some examples, see Charles Lipson, "Lending to the Ptince: Italian. Finance and English Kings in Late Medieval Europe, " mimeograph, University of Chicago, 1988.

51. On the Ottoman Public Debt Administration, see Donald Blaisdel, European Financial Control in the Ottoman Empire (1929; reprint, New York: AMS Press, 1966); D. C. M. Platt, Finance, Trade, and Politics in British Foreign Policy 1815-1914 (Oxford: Clarendon Press, 1968), pp. 181-218; and Feis, Europe, The World's Banker 1870-1914, pp. 313-41. 
tance in the prewar balance of power. However, it is striking that financial cooperation was achieved with relative ease, even as the great powers were engaged in bitter rivalry within the same empire over raw materials, railroads, and other concessions. And this curious combination of financial cooperation and conftict on other economic dimensions recurred throughout the decades before World War I. ${ }^{52}$ More generally, the historical literature indicates quite clearly that the norm in cases of sovereign debt problems was market-based renegotiation in which creditors typically cooperated among themselves with little difficulty. ${ }^{53}$

Roughly the same pattern held in the interwar period, during which the primary lending institutions were based in New York and London. Many of the postwar financial stabilization loans in Europe were arranged by committees made up of representatives of the governments and financial communities of Britain, France, and the United States, often under the aegis of the Financial Committee of the League of Nations. ${ }^{54}$ The Dawes and Young plans each represented collaborative international financial efforts, and the Young Plan included the formation of the Bank for International Settlements (BIS) as a supranational agency to supervise German reparations payments and, more generally, help manage intra-European capital movements. 55

In the minds of some participants in the establishment of the BIS, its promise was even greater. Shepard Morgan, a New York banker with BIS experience,

52. In Tunisia, for example, financial cooperation between France and Italy was accompanied by bitter conflict over agriculture and railroads; see Jean Ganiage, "France, England, and the Tunisian Affair," in Gifford and Louis, France and Britain in Africa, pp. 35-72. For the converse, a failed attempt at financial unilateralism in the Ottoman Empite, see Marian Kent, "Agent of Empire? The National Bank of Turkey and British Foreign Policy," Historical Joumal 18 (June 1975), pp. 367-89.

53. An analytically sophisticated and historically informed literature on the issue is now available. For examples, see Peter Lindert and Peter Morton, "How Sovereign Debt has Worked," in Jeffrey D. Sachs, ed., Developing Country Debt and Economic Performance, vol. 1 (Chicago: University of Chicago Press, 1989), pp. 39-106; Albert Fishlow, "Lessons from the Past: Capital Markets During the Nineteenth Century and the Interwar Period," Intemational Organization 39 (Summer 1985), pp. 383-439 and Albert Fishlow, "Conditionality and Willingness to Pay: Some Parallels from the 1890s," in Barry Eichengreen and Peter Lindert, eds., The Intemational Debt Crisis in Historical Perspective (Cambridge, Mass.: MIT Press, 1989), pp. 86-105. The data in these studies might be brought to bear on the topic of interest here. For example, Lindert and Morton. show that the nominal interest rates on Australian and Canadian bonds (i.e., within the empire) issued before 1914 were roughly the same as those on Japanese bonds and only slightly lower than Argentine and Brazilian bonds. This indicates, as discussed above, that membership in the empire made relatively little difference to lenders, see Lindert and Morton, "How Sovereign Debt has Worked," pp. 49-50. However, this obviously does not control for other variables (economic performance, macroeconomic policies, political stability) presurnably of importance to lenders.

54. On the interwar financial cooperation, see especially Richard H. Meyer, Banker's Diplomacy (New York: Columbia University Press, 1970); and Stephen V. O. Clarke, Central Bank Cooperation 1924-193I (New York: Federal Reserve Bank of New York, 1967).

55. See especially Frank Costigliola, "The Other Side of Isolationism: The Establishment of the First World Bank, 1929-1930, "Joumal of American History 59 (December 1972); Shepard Morgan "Constructive Functions of the International Bank," Foreign Affairs 9 (July 1931), pp. 580-91; and Beth Simmons, "Why Innovate? Founding the Bank for International Settlements, ${ }^{13}$ World Politics 45 (April 1993), pp. 361-405. 
proposed in 1931 that the mandate of the bank (or a similar agency) be expanded so that it could "issue bonds in its own name," then act as "a collateral institution ... capable of granting long-term credits on its own responsibility and at its own risk." By floating loans on national capital markets and relending the proceeds to countries in need of finance, the bank would be "a bridge between countries overstocked with capital and those understocked with it" while remaining "rid . . o of political entanglements." 56 In this manner, it was hoped that the BIS would institutionalize creditor cooperation. ${ }^{57}$

Fledgling attempts at regularizing creditor unity before World War II pale in comparison to the extraordinarily important (if generally indirect) role the International Monetary Fund has played in the complex process of monitoring and enforcing international loan agreements since the $1950 \mathrm{~s} .{ }^{58}$ Creditor cooperation also has been solid as regards government or governmentguaranteed lending, and private financial institutions generally have cooperated among themselves in their interaction with troubled debtors. ${ }^{59}$

If it is not hard to show that creditor cooperation has been common, it is more difficult to demonstrate that force has been used rarely, for the nonexistence of something is hard to document. Nonetheless, most studies that address the issue find few instances of military intervention on behalf of bondholders. ${ }^{60}$ Indeed, some of the cases commonly used to support the charge of debt-related gunboat diplomacy are mischaracterized. The United States had few or no financial interests in the Caribbean nations in which it intervened before 1930, while primary investments were quite substantial. ${ }^{61}$ The 1902 joint European blockade of Venezuela was prompted by threats to resident

56. The quotations are drawn from Morgan, "Constructive Functions of the International Bank," pp. 583 and 588. See also Robert W. Oliver, Early Plans for a World Bank Princeton Studies in. International Finance, no. 29 (Princeton, N.J.: International Finance Section, Princeton University Department of Economics, 1971).

57. In addition to Meyer, Banker's Diplomacy, on the interwar period, see also Barry Eichengreen and Richard Portes, "Debt and Default in the 1930s: Causes and Consequences," European Economic Review 30 (June 1986); Barry Eichengreen, "The U.S. Capital Market and Foreign Lending, 1920-1955," in Sachs, Developing Country Debt and Economic Perfomance, pp. 107-55; and Erika Jorgensen and Jeffrey Sachs, "Default and Renegotiation of Latin American Foreign Bonds in the Interwar Period," in Eichengreen and Lindert, The Intemational Debt Crisis in Historical Perspective, pp. 48-85. A more general survey of the Latin American experience is found in Carlos Marichal, $A$ Century of Debt Crises in Latin America: From Independence to the Great Depression, 1820-1930 (Princeton, N.J.: Princeton University Press, 1989).

58. For an introduction to this vast topic, see Charles Lipson, "The International Organization of Third World Debt," Intemational Organization 35 (Summer 1981), pp. 603-63.

59. Charles Lipson. "Bankers' Dilemmas: Private Cooperation in Rescheduling Sovereign Debts," World Politics 38 (October 1985), pp. 200-225.

60. For two surveys, see D. C. M. Platt, "British Bondholders in Nineteenth Century Latin America-Injury and Remedy," Inter-American Economic Affairs 14 (Winter 1960), pp. 3-43; and Charles Lipson, "International Debt and National Security: Comparing Victorian Britain and Postwar America," in Eichengreen and Lindert. The Intemational Debt Crisis in Histonical Perspective, pp. 189-226. That home governments did not commonly use force does not mean that they did not remonstrate on behalf of their nationals.

61. Frieden, "The Economics of Intervention." 
foreigners and their property by a capricious dictator; the debt issue was insignificant. ${ }^{62}$

Two well-known historical cases do present something of a problem for my analysis: Egypt and India. As noted above, India and the Dominions were frequent borrowers, a fact that contradicts my argument that colonial control not be associated with disproportionately high levels of borrowing. In the case of the Dominions, it is likely that the effects of colonial rule on investment decisions were swamped by two factors. First, by most calculations the governments of Australia, Canada, and New Zealand were independent, and Dominion status meant little from the standpoint of property rights. Second, these areas were not typical of other capital-importing regions: they were high-income and politically very stable. These factors, and several others of a related nature, could easily explain the preference of British investors for Dominion government bonds. Investment in India and Egypt is less clearly explicable.

The analytical problem is different for the two countries. India was a heavy borrower despite its underdeveloped and colonial status: according to one set of figures, 55 percent of British investment in India between 1865 and 1914 was in government bonds. ${ }^{63}$ Two obvious explanations suggest themselves. First, the British government implicitly subsidized Indian bond issues (primarily by allowing them to be used for trust accounts), which increased their attractiveness. Second, India's strategic importance to the British Empire required a massive railroad network, most of which was publicly owned and much of which the British government encouraged to be financed in London. Accurate as these explanations may be, they do not represent support for my approach in this instance; at best, they reflect the potential importance of other factors, which is indubitable.

The relationship between foreign economic interests (including bondholders) and the extension of British control to Egypt is a complex and hotly contested issue. ${ }^{64}$ It is clear enough that Egypt's foreign debt (largely to British and French bondholders) was an important irritant in the country's relations

62. Lipson, "International Debt and National Security," pp. 201-4.

63. Davis and Huttenback, Mammon and the Pursuit of Empire, p. 65. Tomlinson's figures indicate that public debt comprised 63 percent of total British investment in India in both 1921 and 1938. See Tomlinson, The Political Economy of the Raj 1914-1947, p. 49.

64. For excellent survey of recent work, see A. G. Hopkins, "The Victorians and Africa: A Reconsideration of the Occupation of Egypt, 1882," Joumal of African History, vol. 27, no. 2, 1986, pp. 363-91. Among the important studies of elements of the case relevant to the issues at hand are Richard A. Atkins, "The Origins of the Anglo-French Condominium in Egypt, 1875-1876," The Historian 36 (February 1974), pp. 264-82; Agatha Ramm, "Great Britain and France in Egypt 1876-1882," in Gifford and Louis, France and Britain in Africa, pp. 73-119; Jean Bouvier, "Les Intérêts Financiers et la Question d'Egypte" (Financial interests and the Egypt question), Revue historique 3 (July-September 1960), pp. 75-104; F. Robert Hunter, Egypt Under the Khedives 1805-1879 (Pittsburgh, Penn.: University of Pittsburgh Press, 1984); David Landes, Bankers and Pashas (Cambridge, Mass.: Harvard University Press, 1958); and Alexander Schölch, Egypt for the Egyptians: The Sociopolitical Crisis in Egypt, 1878-1882 (London: Ithaca Press, 1981). 
with the European powers and that Egyptian finances were regularized, to the benefit of foreign bondholders, after the British occupation in $1882 .{ }^{65}$ Several considerations, however, mitigate the quick conclusion that the country's foreign debt was the sole or principal cause of the British intervention. The first is the obvious importance of other economic interests in the area-cotton cultivation and exports, the large community of resident investors, and the Suez Canal-all of which contributed to British concern. Indeed, it might well be argued that the Suez Canal was the ultimate example of an overseas asset whose value was site-specific and whose protection by the use of force was particularly feasible. The second consideration is that the Egyptian saga began, like that of the Ottoman Empire, with a joint creditors' committee, in this case an Anglo-French dual control commission. British occupation came as the French left the field, and British unilateralism may have been spurred by the gradual failure of cooperation. In any event, more work needs to be done before all the case's analytical implications are clear. It is, in fact, striking that, while loans represented roughly half of all foreign investment in the developing world before World War I, there are few cases in which even the boldest historians argue for a connection between lending and intervention.

Despite gaps, then, it does appear that sovereign lending was seldom associated with the use of force by home governments. It also appears that such lending typically involved multilateral cooperation among private creditors or their governments.

\section{Implications and conclusions}

By putting forth a relatively simple set of hypotheses such as those discussed here, I do not mean to imply that these variables are the sole or even the most important explanations of colonialism or North-South relations more generally. Everything from relative military capabilities, through geostrategic considerations, to norms of sovereignty would need to be included in a full discussion of the determinants of variation in colonial policy over time and across regions. I do nonetheless argue (1) that economic characteristics of cross-border investments had certain systematic effects on the use of force against host countries and on cooperation among home countries, and vice versa and (2) that the evidence tends to support the validity of this first assertion.

The most direct purpose of this article has been to bring new analytical and empirical evidence to bear on an old debate about the relationship between foreign investment and colonialism. In the interests of analytical clarity, I reframed both the questions and the proposed answers. In so doing, I pointed out that the relevant question is not whether "the economy mattered" but

65. Bent Hansen, "Interest Rates and Foreign Capital in Egypt Under British Occupation," Joumal of Economic History 43 (December 1983), pp. 867-84. 
under what circumstances economic considerations had predictable effects on political outcomes. I believe that the hypotheses put forth help clarify the analytical issues, and the evidence adduced provides at least some indication of the plausibility of my arguments.

Apart from its relevance to explaining the relationship between colonialism and foreign investment, one potential implication of my argument has to do with change over time. It may indeed not be coincidental that the movement away from colonialism has been correlated with a continual decline in the importance of primary investment in the Third World and an increase in sovereign lending and foreign direct investment in manufacturing. The causal arrows may go in either direction, or their direction may vary from case to case. Nonetheless, there appears to be a strong historical association between colonial rule and foreign investment in primary production for export and between independence and foreign borrowing and foreign investment in manufacturing. ${ }^{66}$

However, other implications, of more general interest, have to do with the broad problem of the relationship between different economic interests and international conflict and cooperation. I argued for logically defensible connections between particular characteristics of economic activities (such as site specificity) and the probability of particular types of interstate conflict (such as the use of military force). I also argued that cooperation among investors and their home governments is more likely the greater the scale economies in monitoring and enforcing agreements, and the lower the costs of controlling free riding. ${ }^{67}$ Similar logic could be applied to explore factors influencing various sorts of interstate arrangements, from alliance behavior through regional integration to annexation.

Inasmuch as we seek to explain the importance of different economic activities for patterns of interstate conflict and cooperation, the analysis presented here may hold some lessons. Interstate ties can be regarded as relational contracts, and the analytical tools used here can be brought to bear upon them in similar ways. My approach emphasizes the returns of sharing the costs of monitoring and enforcing agreements and the costs of controlling free-riding among parties to these agreements. A variety of economic and noneconomic interactions appear amenable to this type of analysis. In the economic sphere, for example, we can think immediately of applications to the

66. This suggests a relationship, which. I've discussed in more detait elsewhere, among economic development, foreign investment, and intervention. Less developed societies are likely to attract mostly primary investment, and as they develop they typicaliy begin to attract more complex forms of investment. In this context, countries at lower levels of development may be characterized by a preponderance of foreign primary investments and a propensity on the part of the home country to intervene; this pattern would change as economic development led to a diversification of foreign. investments. See Frieden, "The Economics of Intervention."

67. This portion of the argument parallels that of Fratianni and Pattison in "The Economics of International Organization." 
study of macroeconomic policy coordination, environmental policy cooperation, and the harmonization of regulatory or fiscal policies.

Scholars, observers, and political actors have long debated the political effects of developed-country investments in the developing world. Two dimensions of the debate are central: whether cross-border investments are associated with the use of force by the investing country and whether such investments tend to encourage or impede cooperation among the investing countries. This article argues that the issues can be addressed only by taking account of the differences among various sorts of foreign investments. Some, such as investments in extractive industries or agriculture, appear both logically and historically associated with higher levels of intervention in the host country and conflict among investing nations, leading perhaps to colonial annexation. Others, such as foreign loans, are far less amenable to the use of force and far more favorable to cooperation among investing nations. A reinterpretation of the issue based on the modern literature about relational contracting supports conclusions that clarify historical experience, and for whose empirical relevance there is substantial evidence. Such a reinterpretation also has implications for other analyses of the relationship between cross-border economic activities and interstate conftict and cooperation. 